An International Multidisciplinary Double-Blind Peer-reviewed Research Journal

\title{
The Implementation of Supervision of Madrasah Principal in Developing A Guidance and Counseling Program
}

\author{
Wardatus Sholehah $^{1}$; Ali Nurhadi ${ }^{2}$; Abdul Wafi ${ }^{3}$ \\ Islamic Education Management Study Program, State Islamic Institute (IAIN) of Madura \\ ${ }^{1}$ waratussholehah7@gmail.com \\ 2alinurhadi@iainmadura.ac.id \\ 3 abdulwafi@iainmadura.ac.id
}

\begin{abstract}
The results of this study indicate that: 1) The implementation of the supervision of the madrasah principal in developing the guidance and counseling program has been well implemented and can help, guide, and provide direction to BK teachers in compiling and developing guidance and counseling programs. The steps are carried out in several steps, including preparing a schedule and supervision instrument, notifying the BK teacher who will be supervised, carrying out supervision to the BK teacher by checking the program and monitoring its implementation, and evaluating or assessing the BK program. The technique used in the implementation of the supervision of the madrasah principal is individual and group techniques. Meanwhile, the approach to the supervision of the head of the madrasah is a direct and indirect approach. 2) Factors supporting the implementation of the supervision of the madrasah Principal in developing guidance and counseling programs are cooperation and support from all parties in the school, the existence of a program or supervision schedule, and BK tools in the form of programs and RPL. While the inhibiting factor is the existence of an agenda or schedule for the madrasa principal that coincides with the schedule for the implementation of supervision for BK teachers so that supervision can be delayed. 3) The solution to overcome obstacles in implementing the supervision of the madrasa principal in developing a counseling guidance program is to arrange or change the supervision schedule to another time and coordinate with the BK teacher so that supervision can still be carried out.
\end{abstract}

Keywords: Supervision of Madrasah Principals, Guidance and Counseling Programs.

\section{INTRODUCTION}

Along with the times, all aspects of human life have developed in a more advanced direction. The existing Human Resources (HR) are also required to be of higher quality so that they can compete in the midst of an increasingly developing society. To address it, of course, an effort is needed to improve the quality of existing human resources. In this case, the role of schools is very important to improve the quality of existing human resources, namely through the implementation of education.

Schools are as institution, where education is held, which have the aim of developing all the students' potentials so that they can then prepare themselves to face life in the future. It will be realized and be optimal if the school is used as a formal learning center for students and can develop the existing learning process well and all aspects that influence it (Firdaus \& Hodijah, 2018:113-114).

Schools have a strategic role as a place where education and learning takes place for students. Schools are places for students to develop their potential and to prepare students as the nation's next generation to be more qualified, both in terms of knowledge, attitudes, and 
An International Multidisciplinary Double-Blind Peer-reviewed Research Journal

skills. Schools certainly strive for quality output and have social behavior in accordance with existing norms and values and live in the community.

Schools as learning organizations require coordination between all components in order to achieve the expected educational goals. In managing all the components in the school, it is necessary to have the role of a leader. The leader of this educational unit is usually referred to as the principal of the school/madrasah.

The principal is one component in education that has a role to improve the quality of education (Bermawi \& Faizyah, 2015: 17). A principal can succeed in carrying out his role if he truly understands the state of the school as a complex and unique organization, and is able to carry out his role as someone who has been given the responsibility to lead the school (Sohiron, 2015: 51).

The principal of the school/madrasah is the head of the educational institution unit who has a role to regulate and manage the educational institution he leads so that then he is able to bring the educational institution to achieve the expected educational goals. The principal of the school/madrasah must be able to coordinate all the duties of teachers and other staffs in the school. Therefore, a school/madrasah principal is expected to really understand the state of the school he leads and carries out his role well in order to succeed in carrying out his role as someone who is given the responsibility and duty to become a leader in an educational institution.

As a leader, the principal does not only function as an administrator. The principal also functions as a supervisor who has the task of providing professional services in order to improve the professional competence of teachers and other staffs, either directly or indirectly (Bermawi \& Fauziyah, 2015:17). In this case, it can be seen that a school principal as the head of an educational unit does not only carry out managerial processes, such as managing and regulating educational institutions, but also functions to carry out supervision within the school.

Supervision is an activity that has been planned to provide guidance and assistance to teachers and other school employees so that they can then do their work more effectively (Shulhan, 2012:5). Principal supervision is an activity carried out to observe, supervise, and provide guidance on activities carried out by others with the aim of making improvements to the process and activities/work carried out (Suparno, 2016: 188).

The principal carries out supervision activities to help teachers and other staff/employees in the school so that they can then do their job well and so that they are more professional in their work. With this supervision activity, teachers and other staff/employees in school can be given assistance, guidance, and direction by the principal with the aim of improving their performance.

In carrying out their duties, the principal must also master the appropriate and suitable strategy, approach, or supervision model to overcome all the problems faced by teachers or other staff/employees in school. Teachers or other staffs in schools certainly have problems or obstacles in doing work. Therefore, supervision activities need to be carried out by school principals to monitor and provide direction so that they can then overcome all problems faced by teachers, including counseling teachers or counselors.

Counseling guidance teachers or counselors certainly already have mastery of skills in their fields, including in the preparation of counseling guidance programs. However, it is possible that counselors still experience problems, such as not adapting the guidance and counseling program to the needs of students so that the program implemented does not develop (monotonous) and makes students bored. 
An International Multidisciplinary Double-Blind Peer-reviewed Research Journal

BK teachers or counselors must have the ability and skills to develop guidance and counseling programs. But in reality, there are still many BK teachers or counselors who are still having problems in preparing the guidance and counseling program. This means that not all BK teachers or counselors are able to develop guidance and counseling programs properly.

This is based on research conducted by Aan Purwanti, Muswardi Rosra, and Yusmansyah in the journal Muh Farozin, et al., regarding the analysis of the performance of counseling teachers in preparing guidance and counseling programs. In this case, the results of this study indicate that the performance of guidance and counseling teachers in conducting guidance and counseling programs is still not good. This is because there are guidance and counseling teachers who do not conduct a prior analysis of every aspect of programming before making the preparation of the program (Farozin et.al, 2017: 42).

From this research, it can be seen that the ability and skills of BK teachers in preparing guidance and counseling programs are still lacking, both in analyzing the needs of the counselee (students) and in conducting sustainable programming based on what is needed by the counselee and comprehensively. This of course will affect the guidance and counseling program that will be implemented. Meanwhile, the guidance and counseling program needs to continue to be developed so that it is always in accordance with the needs of the counselee (students). So, in this case, it is necessary to have the supervision of the principal to carry out supervision, guidance, and direction to $\mathrm{BK}$ teachers (counselors) so that later they can develop the guidance and counseling program.

The benchmark for whether or not the performance of BK teachers (counselors) is good can be seen from their abilities and skills in preparing counseling guidance programs before carrying out these service activities. This is because the higher the understanding of a BK teacher (counselor) about the guidance and counseling program, the services provided to the counselee will also be carried out optimally (orderly and completely).

Guidance and counseling programs are very important in the implementation of instruction. This is because in practice, there are some students who are still experiencing problems or difficulties in capturing and understanding the lessons given/delivered by the teacher in the learning process. Students who experience these problems or difficulties certainly need special services, namely in the form of things that can increase their enthusiasm for learning and foster low motivation so that later they will provide encouragement to learn and pursue what they aspire to (Widada, 2013:64).

The existence of principal supervision activities can assist BK teachers (counselors) in conducting the preparation and development of existing guidance and counseling programs. The principal as a supervisor will guide and direct BK teachers (counselors) so that they can then develop good guidance and counseling programs that are in accordance with the needs of the counselees (students) and are able to overcome problems or difficulties faced by students in learning. Thus, the implementation of principal supervision can assist in developing guidance and counseling programs in schools.

MTs Negeri 2 Pamekasan is one of the Madrasah whose its principal has supervised the teachers and all staffs in the school. As the statement from Mr. Mohammad Kurni (2020) as follows: "Supervision activities have been carried out by the head of the madrasa at MTs Negeri 2 Pamekasan. Supervision is important to be carried out by the madrasa principal to monitor or supervise teachers and all staffs in the school in carrying out their work.

Based on this statement, it can be seen that the supervision of the madrasah principal at MTs Negeri 2 Pamekasan has been carried out properly. This supervision activity 
An International Multidisciplinary Double-Blind Peer-reviewed Research Journal

is carried out to monitor all teachers and staffs in carrying out their work and develop programs, including guidance and counseling programs. As stated by one of the BK teachers at MTs Negeri 2 Pamekasan, Mrs. Anisatun Mutmainnah as follows:

"The head of the Madrasah at MTs Negeri 2 Pamekasan has carried out supervision activities for all teachers, including counseling teachers (counselors). Every semester there must be supervision from the head of the madrasa to monitor teacher performance in carrying out work or monitoring program implementation. It's just that sometimes this supervision activity is not carried out according to a predetermined time, because the head of the madrasa has other activities. However, the principal can replace it at another time. If for counseling guidance teachers, it means that they are being monitored when carrying out counseling guidance services to students. The implementation of the counseling guidance program carried out by the BK teacher is always monitored and assessed by the head of the madrasa. For example, the BK program enters the classroom to provide counseling guidance, the head of the madrasa can monitor when the BK teacher provides counseling guidance services to students. In addition, BK teachers also provide reports to the head of the madrasa regarding the implementation of the counseling guidance program, so that the head of the madrasa can find out about the implementation of the program. If there are problems in the implementation of the counseling guidance program, then the head of the madrasa provides input or direction to the BK teacher so that the next program can be developed."

Based on this statement, of course, it can be seen that the supervision of the madrasah principal at MTs Negeri 2 Pamekasan has been carried out and can assist in developing the guidance and counseling program at the educational institution. The head of the madrasa always strives to assist BK teachers (counselors) in developing existing counseling guidance programs.

From the explanation above, the researchers are interested in conducting research entitled "The Implementation of Madrasah Principal's Supervision in Developing Guidance and Counseling Programs at MTs Negeri 2 Pamekasan".

\section{RESEARCH METHODS}

This research uses a qualitative approach, namely descriptive research. According to Bogdan and Taylor in Moleong, qualitative research is a research procedure that produces descriptive data in the form of written or spoken words from people (speech) and observable behavior (2017:4). The type of research used in this research is descriptive research. Descriptive research designs answer who, what, when, and how questions of a particular study. Descriptive research is used to obtain information about the status of variable phenomena or situation and conditions (Nurdin \& Hartanti, 2019: 37). Qualitative research with descriptive type is used by researchers because this study wants to understand more deeply about the implementation of madrasah principal's supervision in order to develop a guidance and counseling program at MTs Negeri 2 Pamekasan by describing, presenting or providing an overview of the implementation of madrasah principal's supervision in developing the guidance and counseling program at MTs Negeri 2 Pamekasan to be more specific, transparent, and in-depth.

Data collection in this study used three techniques, namely as follows; a) Interview technique; an interview is a conversation or dialogue conducted by the two parties, namely the interviewer who ask questions and interviewees that provide answers to the questions 
An International Multidisciplinary Double-Blind Peer-reviewed Research Journal

posed. (Moleong, 2017: 186). This study uses a semi-structured interview type, namely in this interview there is an interview guide that is used as a benchmark for the flow, sequence, and use of data. The contents written in the interview guide are in the form of topics of conversation that refer to one central theme that has been determined, namely the implementation of the madrasah principal's supervision in developing the guidance and counseling program at MTs Negeri 2 Pamekasan. b) Observation Techniques. Observation is a method of collecting data by conducting direct observations to the object of research to take a closer look at the activities carried out. This study uses a data collection method in the form of non-participant observation, that is, the researcher is not part of the group being studied (headmaster or teacher at MTs Negeri 2 Pamekasan). The researcher did not participate in the group being studied or did not participate in the activity, only played a role in observing the activity. The researcher here only acts as an observer to make direct observations of matters relating to the implementation of the madrasah principal's supervision in order to develop a guidance and counseling program at MTs Negeri 2 Pamekasan. The reason for choosing this observation technique is so that researchers can focus more on observing the object being studied. c) Documentation Techniques. Documentation is looking for data about things or variables in the form of notes, transcripts, books, newspapers, magazines, inscriptions, minutes, linger, agendas, and so on (Siyoto \& Sodik: 77-78). Documentation in this study is to obtain data that can support this research in the form of pictures or photos such as interview photos, photos of the implementation of the supervision of the head of the madrasa, guidance and counseling program documents, and other photos related to the problems to be studied in MTs Negeri 2 Pamekasan. In addition, it can also be in written form such as drafts of interview and observation guidelines.

This study uses data analysis with the model proposed by Miles, Huberman, and Saldana to NBC Neolaka Melchizedek is as follows: a) Reduction Data; to reduce data means to make summary, to choose things that are basic, to focus on matters of the important thing, to look for themes and patterns. Thus the data that has been reduced will provide a clearer picture, and make it easier for researchers to conduct further data collection, and to look for it when needed. b) Displaying Data; namely after the data is reduced, the next step is to display the data. In qualitative research, data presentation can be done in the form of brief descriptions, charts, relationships, between categories, flowcharts and the like. c) Conclusion Drawing/Verification, namely drawing conclusions and verification. The initial conclusions put forward are still tentative, and will change if there is no strong evidence that supports the next stage of data collection. But if the conclusions put forward in the early stages, supported by reliable and consistent evidence when researchers returned to the research setting to collect data, then the conclusions drawn is the credible conclusion (Sugiyono, 2011: 246252).

\section{DISCUSSION}

\section{The Implementation of Madrasah Principal's Supervision in Developing Guidance and Counseling Programs at MTs Negeri 2 Pamekasan}

Supervision of madrasah principals is an activity carried out to monitor, guide, foster, or provide direction to their subordinates, namely teachers and other school employees in order to overcome all existing problems in order to make improvements to achieve educational goals. In the realm of guidance and counseling programs, the role of the principal as a supervisor is very necessary so that later he can provide assistance, guidance, and 
An International Multidisciplinary Double-Blind Peer-reviewed Research Journal

coaching to BK teachers in particular so that they can always develop and develop existing guidance and counseling programs.

As explained by Sugiyo that in the realm of guidance and counseling, the madrasah principal has the following roles; a) Determining or selecting a coordinator for guidance and counseling. b) Providing facilities and infrastructure, facilities, and other things that can facilitate and support the implementation of guidance and counseling. c) Provide input in the preparation of guidance and counseling programs. d) Carrying out monitoring and supervision activities as well as coaching the guidance and counseling personnel. e) Being responsible for the implementation of guidance and counseling to the relevant agencies or to the parents of students. f) Disseminating guidance and counseling activities on guidance and counseling activities to stakeholders and other parties who need to obtain information about guidance and counseling in the school. g) Improving the skills and abilities of counselors by sending counselors to attend trainings and seminars or other similar activities (Sugiyono: 2015: 41).

To implement the supervision of the madrasah principal, it is necessary to have a plan with the preparation of a program or schedule, the implementation of supervision that is adjusted to the schedule, and then followed up.

The implementation of the supervision of the madrasah principal in developing the guidance and counseling program at MTs Negeri 2 Pamekasan is carried out by first preparing the supervision program, which includes the preparation of a schedule of supervision activities and the manufacture of supervision instruments in which there are aspects that will be assessed in the supervision of the head of this madrasa. In preparing or making this supervision schedule, the madrasah principal coordinates with teachers and other school staffs to determine the appropriate supervision schedule in accordance with the teaching hours of subject teachers or the schedule of BK services for BK teachers.

As explained by Yusmadi, et al. that before carrying out or implementing supervision of teachers, the program must first be prepared by having clear formulas that include the objectives and tools needed in supervision. This supervision program does not only include a supervision schedule, but also includes an assessment format and supervision instruments (p.89-90).

In this case, it can be seen that before implementing a supervisory activity for the madrasa principal in developing a guidance and counseling program, planning must first be carried out, namely by compiling a supervision program which includes a supervision schedule and supervision instruments that will be used to conduct an assessment in the supervision activities of BK teachers or counselor.

The implementation of supervision is the realization of a predetermined program or schedule. To carry out or to implement the supervision of the madrasa principal in order to develop a guidance and counseling program at MTs Negeri 2 Pamekasan, the madrasah principal will notify in advance when it will be carried out according to a predetermined schedule. In the implementation of supervision, the madrasah principal will see or check the BK program compiled and deposited by the BK teacher. Then the madrasah principal will monitor the implementation of the BK program when supervising the BK teacher.

As explained by Burhanuddin in Donni and Sonny (2018: 250), that there are several important things that need to be considered in the implementation of academic supervision, namely as follows; a) Supervision should be carried out by making advance preparations and systematic/systematic planning. b) Supervision should be carried out by notifying the parties who will be involved or related to supervision activities. c) Supervision should be carried out using several techniques and methods to produce comprehensive 
An International Multidisciplinary Double-Blind Peer-reviewed Research Journal

results. d) Need to prepare the necessary instruments in supervision activities. e) Should make a report to the parties concerned after the implementation of supervision.

In the implementation of the Madrasah Principal's supervision surely there are certain techniques to use. The technique used in implementing the supervision of the madrasah principal in developing the guidance program at MTs Negeri 2 Pamekasan is adapted to the situation and conditions that exist in this madrasa, which includes individual and group supervision techniques. In general, the technique used in supervising the principal of this madrasa is an individual technique, namely by making class visits or the BK room to monitor the BK teacher when providing guidance and counseling services to students. BK technique is done because teachers have a program that is different from one another, so that the individual techniques are considered more effective in the implementation of this supervision. However, at certain times, this supervision is carried out using a group technique if there are problems regarding BK that are general in nature and need to be discussed together. This group technique can be done by making this right a meeting with the teachers.

In this case, as explained by Muwahid Sulhan that in general this supervision technique can be divided into two, namely (a) individual techniques and (b) group techniques. Individual supervision techniques are by conducting class visits, class observations, guiding teachers to find out how to learn and understand the personality of students and ways to overcome problems owned by students, as well as guiding teachers in all matters related and related to the implementation of the school curriculum. Meanwhile, group supervision is carried out through holding meetings or meetings with teachers, holding group discussions, and conducting upgrading (2012: 59-60).

In the implementation of the supervision of the madrasah principal does not only pay attention to the technique used, but also pay attention to the supervision approach. Umiarso and Imam Gojali in Sohiron, divide the supervision approach into three, namely directive (direct), non-directive (indirect), and collaborative approaches. The directive approach (direct) is an approach to the problem directly carried out with the supervisor providing input, direction or guidance directly to the teacher (the person being supervised). The non-directive (indirect) approach is an indirect approach to problems that is carried out by the supervisor listening to whatever is communicated or put forward by the teacher regarding the problems or difficulties he or she is experiencing. Meanwhile, the collaborative approach is done by combining the two approaches, namely the direct and indirect approaches (2015: 181-182).

This is in line with the research findings that the researchers found, namely that the approach used in supervising the madrasah principal in developing the guidance and counseling program at MTs Negeri 2 Pamekasan depends on the need, which can use a direct or indirect approach. The direct approach is carried out with the principal of the madrasa who directly goes to the teacher and supervises the contents. Meanwhile, the indirect approach is carried out with the BK teacher who first goes to the head of the madrasa to discuss or communicate the problems he faces in implementing the BK program.

Furthermore, after carrying out the supervision of the principal of the madrasa, then the supervision activities carried out by the madrasa principal are followed up to find out the results of the supervision activities that have been carried out. The follow-up to the implementation of the supervision of the madrasah principal in developing the guidance and counseling program at MTs Negeri 2 Pamekasan was carried out based on the evaluation results or notes in the supervision instrument where the principal's supervision instrument will provide a score and a related note what things need to be added right or corrected by the teacher BK, included in the BK program itself. Then the follow-up activity is by doing a 
An International Multidisciplinary Double-Blind Peer-reviewed Research Journal

founding and resolving the problems or deficiencies that exist so that later can develop existing guidance and counseling program.

In this case, as explained in the journal of education management compiled by Anissyahmai, et al. (2017: 95), that follow-up activities are follow-up activities after the implementation of supervision by the principal. Where later the advantages or disadvantages of supervised teachers need to be recorded or recorded objectively by the principal (supervisor) in the assessment instrument. The results of the assessment or these records can later be used to conduct coaching, both individually and in groups. The madrasa principal must follow up by means of; a) Reviewing notes or assessment results from supervision activities that have been carried out. b) Providing guidance to teachers as a follow-up step that is carried out individually or in groups.

\section{Supporting Factors and Inhibiting Factors for Supervision of Madrasah Principal in Developing Guidance and Counseling Programs at MTs Negeri 2 Pamekasan}

In implementing the supervision of the madrasah principal in order to develop guidance and counseling programs surely there are factors that support or hinder those activities. Factors supporting the implementation of the supervision of the madrasah principal in developing the guidance and counseling program at MTs Negeri 2 Pamekasan are the existence of a previously planned supervision program or schedule, the existence of a BK device containing BK and RPL (Service Implementation Plan) programs, as well as the coordination and support from all parties in the madrasa such as the principal, teachers, and other staffs.

In line with this, as explained by Yudha in Cut Nurul Fahmi, et al. (2018:106), that the supporting factor in supervision activities is humans. The human factor shows the involvement of both parties in supervision activities, namely supervisors and teachers. Moreover, both of them coordinate with each other and synergize in carrying out or carrying out their respective duties, so that later supervision can be carried out effectively. In addition, this is also in line with research conducted by Mulyawan Safwandy Nugraha (2015: 66) that one of the supporting factors in this supervision is the existence of a supervision program that has been prepared previously.

In this case, it can be seen that humans with the involvement or support of all in educational institutions can be a supporting factor in the implementation of supervision. With the support and good cooperation between supervisors and teachers, supervision can be carried out properly and effectively. In addition, other supporters are also supported by the existence of a program or schedule of supervision and BK equipment which will be supervised by the principal of the madrasa and BK equipment in the form of programs and RPL which will later be supervised by the principal of the madrasa.

The inhibiting actor in the implementation of the supervision of the madrasah principal is the schedule or business of the madrasah principal, such as the implementation of sudden meetings, so that the predetermined supervision schedule can be delayed and it is difficult to determine the time for supervision again because the BK does not have special hours in class learning.

As explained by Cut Nurul Fahmi, et al., that the inhibiting factor in supervision activities is influenced by the number of events such as training and meetings held at the education office so that the predetermined or predetermined schedule is delayed. This is due to a sudden call from the education office to take part in these activities, so the scheduled supervision activities must be abandoned (2018: 117). 
An International Multidisciplinary Double-Blind Peer-reviewed Research Journal

In this case, the inhibiting factor in the implementation of the supervision of the madrasah principal in developing the guidance and counseling program is the existence of other events that need to be carried out, causing delays in the supervision schedule that has been planned or determined in advance.

\section{Solutions to Overcome Barriers to Supervision of Madrasah Principals in Developing Guidance and Counseling Programs at MTs Negeri 2 Pamekasan}

The obstacles in the implementation of an activity need to find a solution so that the activity can run smoothly and in accordance with what is desired, including the implementation of the supervision of the principal of the madrasa in order to develop this guidance and counseling program. The solution to overcome obstacles in implementing the supervision of the madrasah principal in developing a guidance and counseling program at MTs Negeri 2 Pamekasan is with the principal of the madrasa together with the teacher communicating and coordinating with each other to plan or re-determine the replacement time for the supervision schedule that had been delayed previously. This is done by means of the principal and the teacher both looking for other time (free time) to supervise according to the schedule of the BK teacher when conducting BK services to students, both in class and in the BK room. This is because BK teachers do not have their own schedule or hours in class, so the madrasa principal needs to coordinate with the BK teacher in advance to determine the right schedule.

\section{CONCLUSION}

Based on the research findings and discussion regarding the implementation of the supervision of the madrasah principal in developing the guidance and counseling program at MTs Negeri 2 Pamekasan as follows:

1. The implementation of the supervision of the madrasah principal in developing the guidance and counseling program at MTs Negeri 2 Pamekasan has been well implemented. Through the implementation of this supervision, the madrasah principal can assist, guide, and provide direction to BK teachers in compiling and implementing guidance and counseling programs, so that guidance and counseling programs can continue to be developed according to school conditions or the needs of students. The implementation of the supervision of the madrasah principal in developing the guidance and counseling program is carried out as follows:

a. The implementation steps are first to make or prepare a schedule and supervision instrument. After that, the schedule will be notified to the teacher. Second, carry out supervision by checking or viewing the guidance and counseling program that has been prepared by the BK teacher and monitoring the implementation of the program. Third, evaluate or assess the program to find out the shortcomings in the program so that it can improve the next guidance and counseling program.

b. The supervision techniques used in the implementation of the supervision of the madrasah principal are individual techniques and group techniques. The individual technique is in the form of individual visits both to the class and to the BK room to monitor the implementation of the guidance and counseling program by the BK teacher. While the group technique in the form of meetings or group discussions.

c. The supervision approach in the implementation of the supervision of the madrasah principal is a direct and indirect approach.

d. Follow-up is carried out based on the evaluation results or notes on the supervision instrument. Then the principal of the madrasa will provide guidance and provide input 
An International Multidisciplinary Double-Blind Peer-reviewed Research Journal

to BK teachers so that later they can overcome problems and complete deficiencies in order to improve the next guidance and counseling program.

2. The supporting factors and inhibiting factors for the implementation of the supervision of the madrasah principal in developing the guidance and counseling program at MTs Negeri 2 Pamekasan are as follows:

a. The supporting factors for implementing the supervision of the madrasah principal in developing the guidance and counseling program at MTs Negeri 2 Pamekasan are cooperation with all parties, the supervision program or schedule, BK tools in the form of BK and RPL programs that have been prepared by BK teachers to be supervised by the madrasah principal.

b. The inhibiting factor for the implementation of the supervision of the madrasah principal in developing the guidance and counseling program at MTs Negeri 2 Pamekasan is the existence of another agenda or schedule for the madrasah principal that concurrently or conflicts with the supervision schedule for the guidance and counseling teacher, causing supervision cannot be carried out according to a predetermined schedule. In addition, there are difficulties in rescheduling because BK does not have special hours in class learning.

3. The solution to overcome obstacles in implementing the supervision of the madrasah principal is to find or change the supervision schedule that has been delayed to another time by coordinating with the $\mathrm{BK}$ teacher. Then, later the principal of the madrasa will communicate or notify the BK teacher concerned regarding the replacement schedule.

\section{REFERENCES}

Anissyahmai, et al. Academic Supervision of the Principal of Madrasah. Journal of Education Managers. Volumes 11. Number 1. March 2017.

Bermawi, Yoserizal and Tati Fauziah. "Supervision of the Principal of the Professional Competence of Teachers" . Basic Enchantment Journal. Vol. 1. No. 4. 2015.

Fahmi, Cut Nurul, et al., " Implementation of Academic Supervision in Improving the Competence of Elementary School Teachers ". Journal of Science Serambi . Vol. 19. No. 2. September 2018.

Farozin, Muh, et al. " Identification of Problems in the Design of Guidance and Counseling Programs for Vocational Teachers in the City of Yogyakarta" . Journal of Educational Science Research. Volume 10. Number 1. 2017.

Moleong, Lexy. J. Qualitative Research Methodology. Bandung: PT Youth Rosdakarya, 2017.

Nugraha, Mulyawan Safwandy . "Implementation of Academic Supervision by the Head of Private Aliyah Madrasah in Sukabumi Regency, West Java ". Journal of Islamic Education. Vol. 9. No. 1. April 2015.

Nurdin, Ismail and Sri Hartanti. Social Research Methodology. Surabaya: Media Friends of Cendikia, 2019. 
An International Multidisciplinary Double-Blind Peer-reviewed Research Journal

Nurfirdaus, Nunu and Nursitti Hodijah. "Study on the Role of the School Environment and the Formation of Social Behavior of SDN 3 Cisantana students". Educator Scientific Journal . Volume 4. No.2. 2018.

Priansa, Donni Juni and Sonny Suntani Setiani. Education Management and Supervision. Bandung: Rosdakarya Youth, 2018.

Shulhan, Muwahid. Education Supervision. Surabaya: Acima Publishing, 2012.

Siyoto, Sandu and Ali Sodik. Basic Research Methodology. Yogyakarta: Media Literacy Publishing, 2015.

Sohiron. Education Administration and Supervision. New Week: Educational Creations, 2015.

Sugiyono. Quantitative, Qualitative, and R\&D Research Methods. Bandung: Alfabeta, 2015.

Suparno." Academic Supervision of Guidance and Counseling Teachers ". Journal of Educational Managers. Volume 10. Number 2. 2016.

Widada. "Guidance and Counseling Program in Elementary School". Journal of Elementary Thought and Development. Volume 1. Number 1. 2013.

Yusmadi, et al.. " Implementation of Education Supervision at Madrasah Aliyah Negeri 1 Sigli ". Journal of Educational Administration. Vol. 1. No. 1. 